\title{
Influence of Processing Variables on Clay-Based Ceramic Formulations
}

\author{
Julliana Marques Rocha de Figueirêdo *®D, José Rodrigo Sousa Silva ${ }^{a}$, Gelmires de Araújo Neves ${ }^{a}$ \\ Heber Carlos Ferreira ${ }^{a}$, Lisiane Navarro de Lima Santana ${ }^{a}$ \\ ${ }^{a}$ Centro de Ciências e Tecnologia - CCT, Universidade Federal de Campina Grande - UFCG, Aprígio \\ Veloso, 882, Campina Grande, PB, Brasil
}

Received: August 01, 2018; Revised: December 18, 2018; Accepted: February 15, 2019

\begin{abstract}
The properties of ceramic materials and microstructural changes are dependent on the raw materials from which they are made and on the manner in which they are processed, from the composition to the established thermal treatment, heating rate, and firing temperature. In this study, the influence of some processing parameters (formulation, maturation time, and firing temperature) on the physical-mechanical properties and microstructural aspects of ceramic pieces produced from natural aluminosilicates was investigated. Because Brazil does not have many quality ball clays reserves, bentonite was included as a plasticizing agent in this study. The formulations were submitted to maturation for a period of one to four weeks and their characteristics were determined to evaluate plasticity. Following this, the specimens were extruded and subjected to heat at temperatures of 1200,1300 , and $1400^{\circ} \mathrm{C}$. The physical-mechanical properties determined were: water absorption, linear retraction, and flexural strength. Statistical analysis was applied. The results showed that, for the analyzed masses, neither the maturation time nor the physical and mechanical properties analyzed had influence on plasticity. The firing temperature was the factor that generated the greatest alteration in results, increasing the mechanical resistance and altering the size and interlocking of the mullite needles.
\end{abstract}

Keywords: clay, processing variables, mechanical properties.

\section{Introduction}

The mechanical properties of ceramic products are dependent on their composition ${ }^{1,2}$ and processing conditions. Some studies found in the literature deal with the influence of maturation time on the use of kaolin, and it has been verified that this variable influences the physical-mechanical properties of ceramics ${ }^{3}$.

In addition to composition and maturation time, the conformation step is fundamentally important, because it is during this process that the material acquires its desired structural shape and characteristics. Several methods of conformation can be used during processing, which can interfere in the preferential orientation of particles and favor the production of ceramic pieces with different properties ${ }^{4,5}$.

The processing parameters of ceramics masses containing aluminosilicates have been studied at the Federal University of Campina Grande in recent years, with significant results ${ }^{6,7}$. Figueirêdo et al. ${ }^{7}$ evaluated some of the processing parameters of clay-based ceramic masses that had been shaped by uniaxial pressing for use in the manufacture of refractory materials. The results showed that the chemical and granulometric composition of the clays, as well as the processing variables, influenced their physical-mechanical properties. Based on the refractoriness and mechanical strength values, the authors suggested that they could be used for refractory ceramic

*e-mail: jullymrc@gmail.com product applications like refractory bricks, furnace linings and crucibles.

The most common methods of conformation in the ceramic tile manufacturing process are: pressing ${ }^{8,9}$, extrusion ${ }^{10}$, and tape casting ${ }^{5}$. Among these, the extrusion process is widely used in traditional ceramics. Some authors assert that the shear stress during conformation does not cause a change in the shape of the particles due to their high modulus of elasticity but may change their orientation ${ }^{4,11,12}$.

Another processing variable that strongly influences mechanical properties is the firing temperature. Silva et al. ${ }^{13}$ produced porous blocks of mullite through uniaxial pressing of compositions containing kaolin and alumina residue using a conventional kiln heat treatment at elevated temperatures $\left(1450\right.$ and $\left.1500^{\circ} \mathrm{C}\right)$. The authors observed that the water absorption values and apparent porosity decreased with increasing temperature, contributing to a higher density and increase in mechanical strength, which is also related to the phase transformations, especially the increase in the mullite content.

Kaolinite, composed mainly of alumina and silica, undergoes a series of reactions in which the oxides combine to favor nucleation and growth of mullite crystals, a phase that greatly influences the mechanical properties ${ }^{14}$. Resulting from thermal treatments above $1000^{\circ} \mathrm{C}$, mullite is one of the most important crystalline phases, being found in the final composition of ceramic pieces obtained from clays and occupying a prominent position in the ceramic industry 
due to the abundance of raw materials from which it can be formed and the wide range of its applications ${ }^{15,16}$.

In recent years, several studies have been published attempting to analyze the behavior of minerals related with ceramic processing and transformations during heating. Those studies dealt mainly with the use of kaolinitic raw materials incorporation into ceramic formulations for the production of porcelain, mullite bodies, refractory bodies and zeolites $^{7,12,17-19}$. Some authors ${ }^{20-22}$ have reported that kaolin does not provide sufficient plasticity to the mass, therefore, it is necessary to add small amounts of plastic clay, such as ball clays and bentonites, to provide workability.

The components and processing conditions may interfere with the properties of the ceramic parts. In the literature consulted, very restricted studies have emphasized the effects of the characteristics of the ceramic mass, the maturation time, the conformation method, and the firing temperature on the mechanical properties and microstructures of pieces produced with compositions rich in kaolin. These aspects are of fundamental importance, since the properties of the materials are directly related to the processing variables. Therefore, the objective of this study was to analyze the influence of formulation, maturation time, and firing temperature on the physical-mechanical properties and microstructural aspects of ceramic pieces produced from clay-containing material.

\section{Materials and Methods}

Clays of the following types were utilized in this study: kaolin, supplied by the Rocha Minérios company located in the municipality of Juazeirinho, PB, denominated clay A; plastic clay, supplied by the Armil Mineração do Nordeste company located in Parelhas, RN, with clay coming from the municipality of Oeiras, PI, referred to as clay B; and bentonite, a natural polycationic bentonite clay from the municipality of Cubati, PB, referred to as clay C.

Two compositions were prepared from the raw materials to establish a proportion of clays that favored workability, shown in Table 1.

Before the conformation stage, the plasticity of the masses was determined, by the Atterberg method, according to the methodology of ABNT NBR $6459^{23}$ and NBR $7180^{24}$. The ceramic masses with moisture content adequate for the conformation process were matured for periods of 1 , 2,3 , and 4 weeks, in order to improve the homogenization of moisture. Maturation time was chosen as a variable to be analyzed for the manufacture of white ceramic over a four-week period.

Table 1. Composition of ceramic masses utilized

\begin{tabular}{lccc}
\hline Formulation & Clay A & Clay B & Clay C \\
\hline F1 & $90 \%$ & $10 \%$ & - \\
F2 & $90 \%$ & - & $10 \%$ \\
\hline
\end{tabular}

The extrusion process was used to prepare the specimens, with a rectangular mold matrix (Sew do Brazil LTDA, model FZ52M6). After this stage, the specimens were dried in an oven at $110^{\circ} \mathrm{C}$ for $24 \mathrm{~h}$ and then subjected to the firing process at temperatures of 1200,1300 , and $1400^{\circ} \mathrm{C}$, with a heating rate of $5^{\circ} \mathrm{C} / \mathrm{min}$ and maintaining the maximum firing temperature for $60 \mathrm{~min}$. Cooling to room temperature occurred within the oven itself.

After firing, the physical-mechanical properties of the ceramic were determined: water absorption, linear retraction, and flexural strength at three points. For each physicalmechanical property, statistical analysis was performed using a completely randomized design in a $4 \times 3$ factorial scheme (maturation time: 1, 2, 3, and 4 weeks, and temperature: 1200 , 1300 , and $1400^{\circ} \mathrm{C}$ ) with ten replications using the statistical software ASSISTAT 7.725. To compare between the averages, the Tukey test was applied at a 5\% probability level.

The mineralogical characterization of the crystalline phases formed during thermal treatment was performed by $\mathrm{X}$-ray diffraction using a Shimadzu X-ray diffractometer, model XRD-6000, operating with $\mathrm{CuK} \alpha$ radiation, operating voltage of $40 \mathrm{kV}$, current of $30 \mathrm{~mA}$, step size of $0.02^{\circ}$ and scanning angle $2 \theta$ ranging from 5 to $60^{\circ}$. Crystalline phase quantification was performed using the Internal Standard Method by comparing the strongest line of the analyzed phases with the strongest line from a standard reference material, corundum (cor). This methodology used the I/Icor presented in the Joint Committee on Powder Diffraction Standards (JCPDS) cards, determined from a mixture of equal parts, by weight, of the analyzed phase and corundum. Calculus was performed by the Shimadzu software (Search Match: untitled-XRD: Qualitative Analysis) and the JCPDS cards were defined using the PCPDFWIN database of the XRD6000 program. The calculation of crystallinity degree was determined using the relation between the integrated area of the amorphous background line and the integrated intensity of the diffraction reflections.

To analyze the samples fracture surface, a Shimadzu SSX-550 scanning electronic microscope was used, with $20 \mathrm{kV}$ tension and $60.000 \mathrm{X}$ magnification. The samples were covered with gold. The glassy phase was removed by etching the sintered specimens with concentrated HF acid, at $40 \%$ per 10 minutes at room temperature.

\section{Results and Discussion}

The raw material and ceramic masses chemical compositions are in Table 2.

For the raw materials, it was observed that the major oxides were silicon oxide (45.7-54.5\%) and aluminum oxide (27.5-39.5\%), which are related to the presence of mineral clay. The high content of silicon oxide, above that of the mineralogical composition of the clay minerals, indicates the presence of free silica. 
Table 2. Chemical composition of the raw materials and of the ceramics masses (Figueirêdo et al., 2018)

\begin{tabular}{|c|c|c|c|c|c|c|c|c|c|}
\hline \multirow{2}{*}{ Samples } & \multicolumn{9}{|c|}{ Óxides (\%) } \\
\hline & $\mathrm{SiO}_{2}$ & $\mathrm{Al}_{2} \mathrm{O}_{3}$ & $\mathrm{Fe}_{2} \mathrm{O}_{3}$ & $\mathbf{K}_{2} \mathbf{O}$ & MgO & $\mathrm{CaO}$ & $\mathrm{TiO}_{2}$ & Other & LOI \\
\hline Clay A & 45.7 & 39.5 & 0.5 & 0.9 & - & - & - & 0.2 & 13.3 \\
\hline Clay B & 54.5 & 27.5 & 2.6 & 4.0 & 1.5 & 0.8 & 0.9 & 0.6 & 7.7 \\
\hline Clay C & 46.8 & 29.1 & 6.4 & 0.5 & 2.5 & 0.8 & 1.2 & 1.6 & 11.2 \\
\hline $\mathrm{F} 1$ & 45.1 & 37.9 & 0.6 & 1.1 & 0.8 & - & 0.1 & 0.2 & 14.3 \\
\hline $\mathrm{F} 2$ & 44.6 & 38.5 & 0.8 & 0.7 & 1.1 & 0.1 & 0.1 & 0.2 & 13.9 \\
\hline
\end{tabular}

LOI - Loss on ignition measured after drying at $110^{\circ} \mathrm{C}$ and firing at $1000^{\circ} \mathrm{C}$.

Regarding alkaline and earthy alkaline oxides, it was observed that clay $\mathrm{B}$ contained a high quantity of $\mathrm{K}_{2} \mathrm{O}(4.0 \%)$ and clay $\mathrm{C}$ a high quantity of $\mathrm{MgO}(2.5 \%)$. These act as fluxes, contributing to the formation of vitreous phase and decreasing refractoriness ${ }^{26}$. The B clay presented chemical composition similar to the ball clay from Oeiras Municipality in Brazil ${ }^{27}$, which has quartz and mica as accessory minerals. The loss on ignition (LOI) varied between 7.8 and $13.3 \%$.

It was observed that $\mathrm{SiO}_{2}$ and $\mathrm{Al}_{2} \mathrm{O}_{3}$ made up about 45.0 e $38.0 \%$, respectively, of the chemical composition of the ceramic masses. The high quantity of $\mathrm{Al}_{2} \mathrm{O}_{3}$ may be related to the significant presence of kaolinite. A small quantity of $\mathrm{Fe}_{2} \mathrm{O}_{3}$ was found, corresponding to $0.6 \%$ for the $\mathrm{F} 1$ formulation and $0.8 \%$ for the F2 formulation. Amounts below $5 \%$ will favor a light color after firing ${ }^{28}$. The alkali content $\left(\mathrm{K}_{2} \mathrm{O}+\mathrm{MgO}+\mathrm{CaO}\right)$ was low. The principal effect of alkali in clays is to reduce their refractory characteristics. The mineralogical, physical, and thermal characterization of the raw materials and ceramic masses has been shown in another article by the same group.

In Table 3, the Atterberg Limits of formulations F1 and F2 are presented.

Masses with a PI between $1 \%$ and $7 \%$ are considered to be poorly plastic, $7 \%$ to $15 \%$ moderately plastic, and above $15 \%$ highly plastic ${ }^{29}$. The PI values determined for formulations $\mathrm{F} 1$ and $\mathrm{F} 2$ were 13.8 and $15.0 \%$, or moderately plastic $(7 \%<\mathrm{PI} \leq 15 \%)$. The PL of the formulations was about $33 \%$. According to Souza $\operatorname{Santos}^{30}$ the appropriate range for the extrusion process is between 28 and $34 \%$, putting the values found in this study within the suggested range.

The XRD patterns of the evolution of the mineralogical phases of the F1 and F2 samples shaped by extrusion with a maturation time of one week, after thermal treatments of 1200,1300 , and $1400^{\circ} \mathrm{C}$, are presented in Figure 1. The results for the other maturation times for formulations F1 and F2 are not shown, but their behavior is similar.

The following mineralogical phases were observed for all samples: mullite (JCPDS 79-1276), cristobalite (JCPDS 82-0512), and quartz (JCPDS 46-1045), with mullite peaks predominating. The presence of these phases was also observed by Alves et al. ${ }^{31}$ using kaolin-based formulations and a temperature range of $1300-1500^{\circ} \mathrm{C}$.
Table 3. Plasticity of formulations F1 and F2.

\begin{tabular}{lccc}
\hline \multirow{2}{*}{ Samples } & \multicolumn{3}{c}{ Atterberg Limits (\%) } \\
\cline { 2 - 4 } & LL & PL & PI \\
\hline F1 & 47.2 & 33.4 & 13.8 \\
F2 & 48.6 & 33.6 & 14.9
\end{tabular}

LL - Liquid Limit; PL - Plastic Limit; PI - Plasticity Index.

The presence of a small band in $2 \theta$ ranging from $15^{\circ}$ to $25^{\circ}$ can also be observed, principally at temperatures of $1200^{\circ} \mathrm{C}$, which is characteristic of the presence of amorphous material, i.e., vitreous phase due to excess $\mathrm{SiO}_{2}$, as reported in the literature ${ }^{13,32,33}$.

In the F1 and F2 formulations, a cristobalite peak characterized by an interplanar distance of $4.04 \AA$ can be observed. According to Chen et al. ${ }^{34}$, the amorphous $\mathrm{SiO}_{2}$ changes to cristobalite above $1200^{\circ} \mathrm{C}$, then changes to amorphous glass again above $1500^{\circ} \mathrm{C}$. For the $\mathrm{F} 1$ formulations at $1400^{\circ} \mathrm{C}$, reduction in the intensity of this peak can be seen, probably due to the transformation of cristobalite to amorphous phase, clearly seen by the occurrence of a band in $2 \theta$ in the region between 15 and $25^{\circ}$. This behavior may be related to the presence of impurities that can induce a liquid phase during firing, emphasizing for this formulation the presence of $\mathrm{K}_{2} \mathrm{O}$.

The $\mathrm{F} 1$ formulation, with a higher amount of $\mathrm{K}_{2} \mathrm{O}$ and kaolinite, showed less intense cristobalite peaks. The $\mathrm{K}_{2} \mathrm{O}$ inhibits the formation of cristobalite when kaolinite undergoes heat treatments above $1250^{\circ} \mathrm{C}^{35}$. It also was reported by $\mathrm{Aras}^{36}$, who investigated the phase transformations of ball clay.

As the temperature increases, it can be seen that the mullite peaks intensify and the quartz peaks decrease, a behavior observed in both formulations that may be related to a greater interaction between the alumina and silica particles.

In Table 4, the percentages of crystalline phases obtained through standard XRD of the F1 and F2 samples are presented, with a maturation time up to one week after thermal treatments of 1200,1300 , and $1400^{\circ} \mathrm{C}$.

It can be seen in Table 4 that the majority crystalline phase is mullite. Other phases such as quartz and cristobalite are present in smaller proportions. With the elevation of the temperature from 1200 to $1400^{\circ} \mathrm{C}$, the percentage of quartz decreases and the mullite content increases for both samples. 


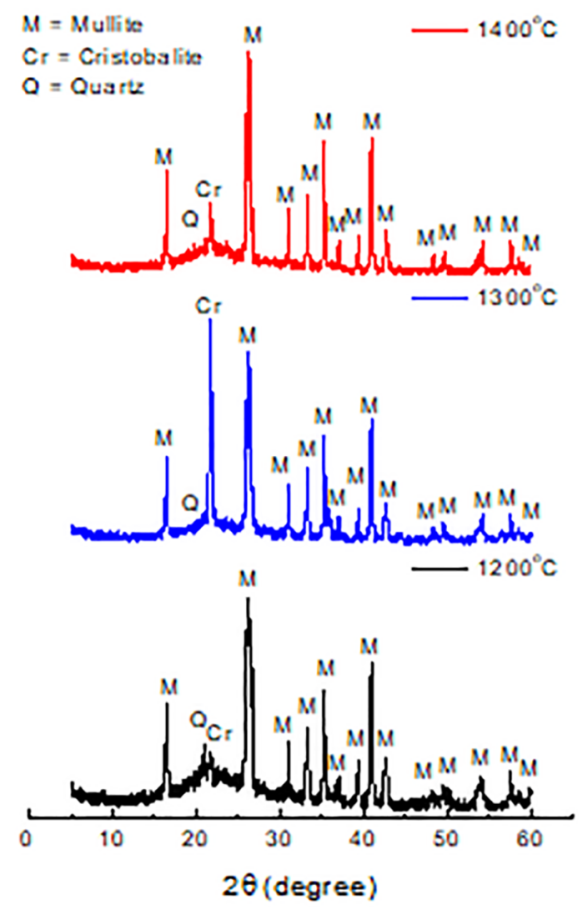

(a)

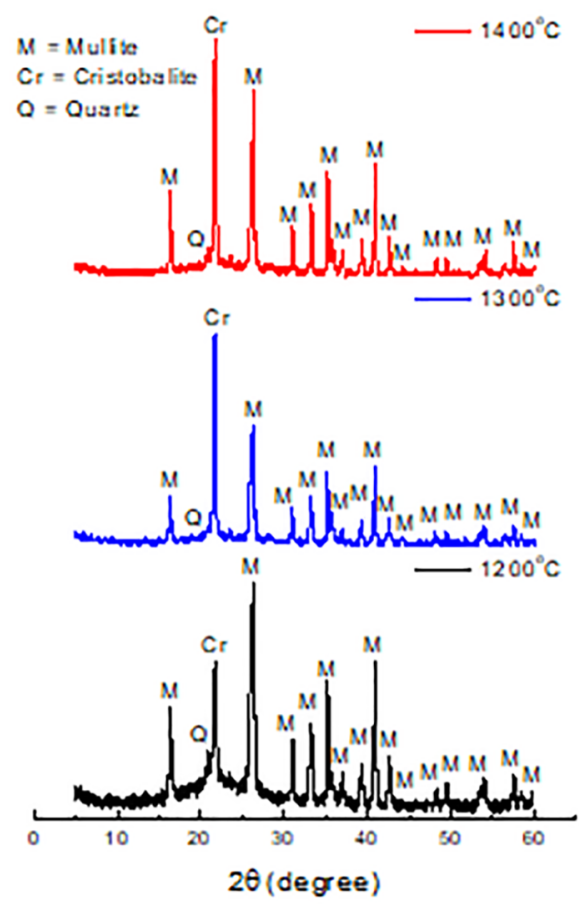

(b)

Figure 1. XRD of the samples following thermal treatment of 1200,1300 , and $1400^{\circ} \mathrm{C}$; with maturation time of one week, for formulations F1 (a) and F2 (b).

Table 4. Crystalline phases of the F1 and F2samples after thermal treatments of 1200,1300 , and $1400^{\circ} \mathrm{C}$ with maturation time up to of one week.

\begin{tabular}{lcccc}
\hline Samples & $\begin{array}{c}\text { Quartz } \\
(\%)\end{array}$ & $\begin{array}{c}\text { Cristobalite } \\
(\%)\end{array}$ & $\begin{array}{c}\text { Mullite } \\
\mathbf{( \% )}\end{array}$ & $\begin{array}{c}\text { \% } \\
\text { Cristalliine } \\
\text { Phases }\end{array}$ \\
\hline $\begin{array}{l}\text { F1- } \\
1200-\mathrm{E}\end{array}$ & 10.7 & 1.1 & 54.8 & 66.7 \\
$\begin{array}{l}\text { F1- } \\
\text { 1300-E }\end{array}$ & 4.2 & 10.5 & 62.6 & 77.3 \\
F1- & 3.7 & 1.7 & 63.1 & 68.4 \\
$\begin{array}{l}1400-\mathrm{E} \\
\text { F2- }\end{array}$ & 10.6 & 4.6 & 58.3 & 73.4 \\
$\begin{array}{l}1200-\mathrm{E} \\
\text { F2- }\end{array}$ & 3.4 & 16.5 & 65.0 & 84.8 \\
$\begin{array}{l}\text { 1300-E } \\
\text { F2- }\end{array}$ & 2.9 & 12.9 & 69.9 & 85.8 \\
$1400-\mathrm{E}$ & 2.9 & & & \\
\hline
\end{tabular}

This may be related to the greater interaction between the silica and alumina particles.

The amount of crystalline phase increased between the temperatures of 1200 and $1300^{\circ} \mathrm{C}$ for both formulations $\mathrm{F} 1$ and F2. An increase in the intensity of cristobalite peaks and mullite phases was also observed (Table 4). At $1400^{\circ} \mathrm{C}$, the crystallinity and intensity of the cristobalite peaks of formulation F1 were observed to have decreased and the amount of vitreous phase increased.

A considerable amount of mullite phase was observed in the sintered compositions at temperatures of 1300 and $1400^{\circ} \mathrm{C}$. According to Bartonickova et al. ${ }^{37}$, the mullitebased ceramic is one of the most suitable candidates for refractory applications.

The micrographs obtained from SEM of formulations F1 and F2, with maturation times between one and four weeks after thermal treatments of 1200 and $1400^{\circ} \mathrm{C}$, are presented in Figures 2 and 3.

The micrographs in Figures 2 and 3 show that thermal treatment at $1200^{\circ} \mathrm{C}$ produced a microstructure characterized by the formation of small mullite needles, probably of primary mullite, since, according to some researchers ${ }^{32,38,39}$, this is the characteristic phase when clays are fired at this temperature. When the temperature is increased to $1400^{\circ} \mathrm{C}$, mullite crystals of larger dimension are observed, occurring from the growth of the previously formed grains, which become more elongated while maintaining the form of needles. This is most likely secondary mullite which is formed from the transient liquid phase, where precipitation of the crystals occurs. In addition, the presence of some dispersed particles is perceptible in the micrographs, which probably originate from quartz and also from the vitreous phase that forms 


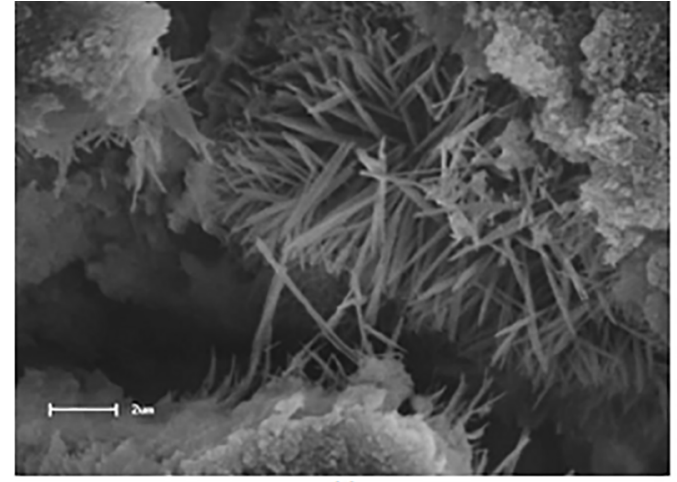

(a)

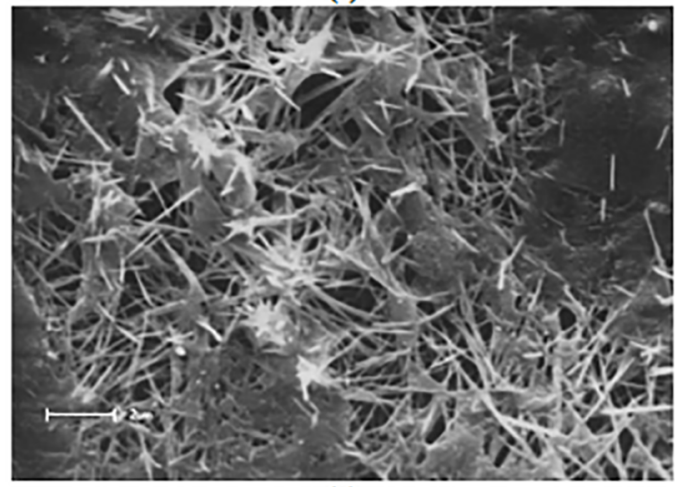

(c)

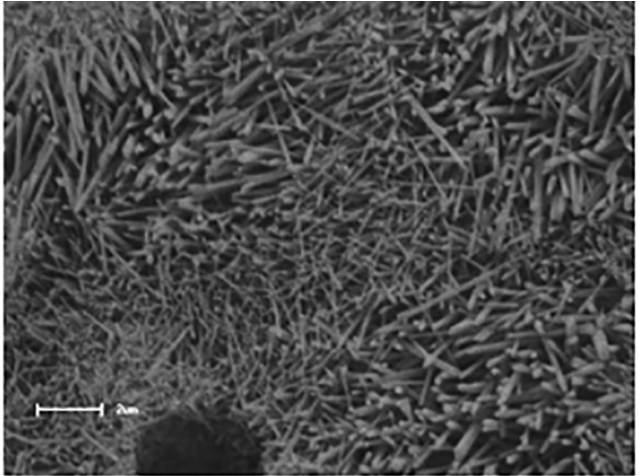

(b)

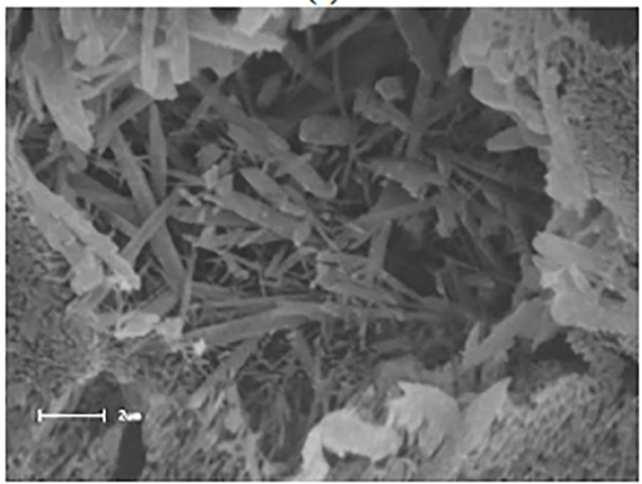

(d)

Figure 2. Micrographs obtained from SEM of the formulation F1 samples after thermal treatment: (a) W1-1200 ${ }^{\circ} \mathrm{C}$; (b) W1-1400 ${ }^{\circ} \mathrm{C}$; (c) $\mathrm{W} 4-1200^{\circ} \mathrm{C}$; (d) $\mathrm{W} 4-1400^{\circ} \mathrm{C}\left(\mathrm{W} 1=1^{\text {st }}\right.$ week; W4 $=4^{\text {th }}$ week $)$.

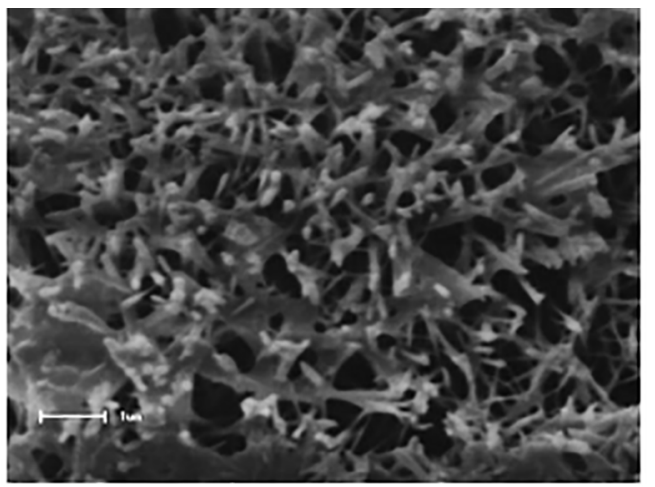

(a)

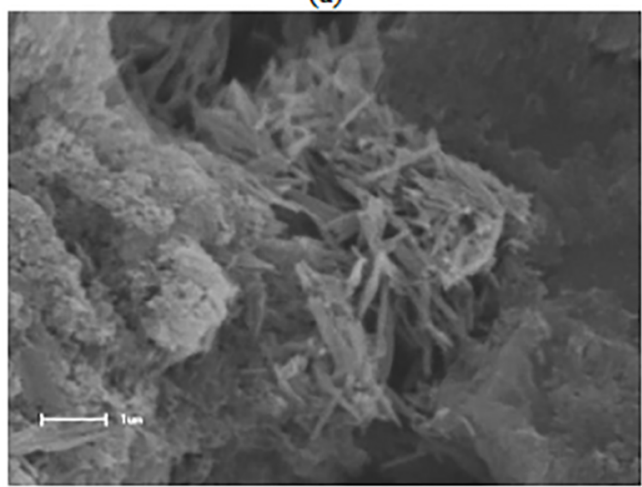

(c)

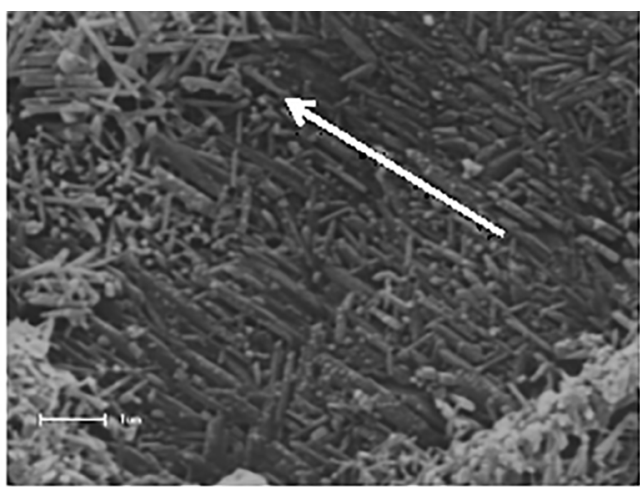

(b)

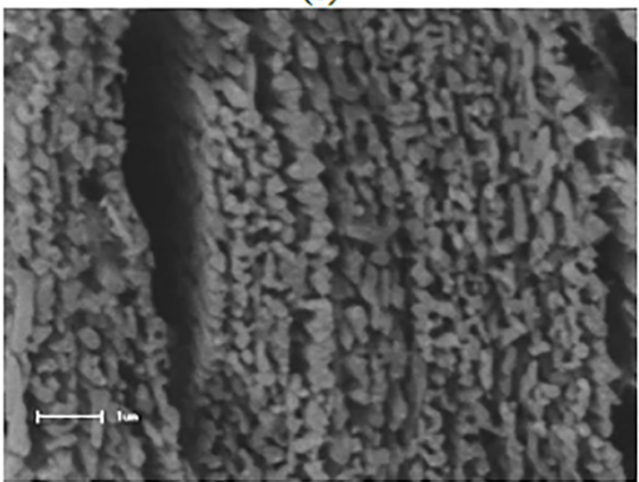

(d)

Figure 3. Micrographs obtained from SEM of the formulation F2 samples after thermal treatment: (a) W1-1200 ${ }^{\circ} \mathrm{C}$; (b) $\mathrm{W} 1-1400^{\circ} \mathrm{C}$ (parallel cut, indicated by the arrow); (c) W4- $1200^{\circ} \mathrm{C}$; (d) W4-1400 ${ }^{\circ} \mathrm{C}$ (perpendicular cut) $\left(\mathrm{W} 1=1^{\text {st }}\right.$ week; $\mathrm{W} 4=4^{\text {th }}$ week). 
from the high temperature liquid. Micrographs with similar aspects were observed by Martín-Márquez et al. ${ }^{40}$, Boussois et al. ${ }^{41}$, and Luo et al. ${ }^{42}$ using the same temperature range.

According to Magliano and Pandolfelli ${ }^{14}$, soluble impurities in the crystal structure of mullite reduce the surface energy in certain directions, leading to a preferential growth in other directions, resulting in the formation of elongated grains. Therefore, the greater the solubility of impurities in mullite, the more acicular the crystal format will be. Piva et al. ${ }^{43}$ further report that lower viscosity of the liquid phase increases diffusion of the species involved in the crystallization of mullite and consequently attenuates the crystal growth. Chen et al. ${ }^{44}$ add that the continuous increase in grain size with increasing temperature indicates the possibility of transformation of primary mullite into secondary mullite.

The presence of cracks was verified in the extruded samples using a perpendicular cut (Figure 3(d)). According to Souza Santos ${ }^{30}$, such behavior may be related to the morphology and ease of preferential orientation under stress, creating tension relief planes along which cracks develop, as the extrusion process requires a larger quantity of water that makes the mass more plastic.

In Figure 3(b), a tendency to align preferentially relative to the parallel cut (indicated by the arrow) can be observed, with the mullite crystals having a specific orientation. Microstructures organized similarly to the extruded samples were observed by Bourret et $a .^{45}$. According to them, extruded materials have a preferred orientation parallel to the direction of extrusion. However, in other studies found in the literature ${ }^{1,4,22,41,45}$, other techniques were used to determine the degree of orientation of the mullite and more precise information about the macroscopic organization, such as: quantitative texture analysis (QTA) and electron microscopy of interferometry.

Table 5 shows the mean water absorption values as a function of temperature and maturation time for formulations $\mathrm{F} 1$ and $\mathrm{F} 2$
For formulations F1 and F2, it can be seen that the samples from the first week absorbed less water at temperatures of 1200 and $1300^{\circ} \mathrm{C}$. At a temperature of $1400^{\circ} \mathrm{C}$, maturation time had no statistically significant influence, and values ranged from $0.6 \%$ to $0.8 \%$ for formulation $\mathrm{F} 1$ and from $1.9 \%$ to $2.1 \%$ for formulation $\mathrm{F} 2$.

When comparing the formulation methods, it can be observed that the F2 formulation, although containing a greater amount of flux oxides $\left(\mathrm{Fe}_{2} \mathrm{O}_{3}, \mathrm{~K}_{2} \mathrm{O}, \mathrm{CaO}\right.$, and $\left.\mathrm{MgO}\right)$, absorbed more water than formulation $\mathrm{F} 1$. This may have occurred because the samples of formulation F1 contain a greater amount of $\mathrm{K}_{2} \mathrm{O}$, which is one of the principal compounds responsible for the formation of the vitreous phase. At temperatures above $1000^{\circ} \mathrm{C}$, this oxide reacts with $\mathrm{SiO}_{2}$ from the decomposition of the clay minerals, forming a liquid phase. This liquid then flows and fills up empty spaces, promoting the approximation of particles through capillary action, increasing the density of the ceramic body ${ }^{46,47}$.

Table 6 shows the mean linear retraction values as a function of temperature and maturation time for formulations $\mathrm{F} 1$ and $\mathrm{F} 2$.

For formulation $\mathrm{F}$ 1, the linear retraction was higher for the first week samples at temperatures of 1200 and $1300^{\circ} \mathrm{C}$. At a temperature of $1400^{\circ} \mathrm{C}$, the first, second, and third weeks showed larger retractions, varying from $14.9 \%$ to $15.5 \%$. For formulation F2, the linear retraction was highest for the first week at temperatures of 1200,1300 , and $1400^{\circ} \mathrm{C}$.

According to the data presented, the linear retraction increases as the firing temperature increases for all of the samples, with the highest values found for the specimens subjected to firing at $1400^{\circ} \mathrm{C}$. This behavior is related to the higher degree of densification caused by physical changes and reduction of the specimen volume. The flux oxides increase the amount of the liquid phase and favor diffusion which, consequently, results in a greater degree of linear retraction.

Table 7 shows the mean values of flexural strength as a function of temperature and maturation time for formulations F1 and F2.

Table 5. Average water absorption values (\%) as a function of temperature and maturation time up to.

\begin{tabular}{|c|c|c|c|c|}
\hline \multirow{2}{*}{ Formulations } & \multirow{2}{*}{$\begin{array}{c}\text { Maturation } \\
\text { time(week) }\end{array}$} & \multicolumn{3}{|c|}{ Firing temperature (oC) } \\
\hline & & 1200 & 1300 & 1400 \\
\hline \multirow{4}{*}{$\mathrm{F} 1$} & $1^{\mathrm{st}}$ & $13.3 \mathrm{cA}$ & $5.2 \mathrm{bB}$ & $0.7 \mathrm{aC}$ \\
\hline & $2^{\text {nd }}$ & $16.7 \mathrm{aA}$ & $6.8 \mathrm{aB}$ & $0.7 \mathrm{aC}$ \\
\hline & $3^{\text {rd }}$ & $14.7 \mathrm{bA}$ & $6.4 \mathrm{abB}$ & $0.6 \mathrm{aC}$ \\
\hline & $4^{\text {th }}$ & $14.7 \mathrm{bA}$ & $6.0 \mathrm{abB}$ & $0.8 \mathrm{aC}$ \\
\hline \multirow{4}{*}{$\mathrm{F} 2$} & $1 \mathrm{st}$ & $13.4 \mathrm{cA}$ & $6.1 \mathrm{bB}$ & $1.9 \mathrm{aC}$ \\
\hline & $2^{\text {nd }}$ & $15.0 \mathrm{bA}$ & $6.6 \mathrm{bB}$ & $2.0 \mathrm{aC}$ \\
\hline & $3^{\text {rd }}$ & $15.3 \mathrm{bA}$ & $8.2 \mathrm{aB}$ & $2.1 \mathrm{aC}$ \\
\hline & $4^{\text {th }}$ & $16.8 \mathrm{aA}$ & $8.7 \mathrm{aB}$ & $2.1 \mathrm{aC}$ \\
\hline
\end{tabular}

Note: The averages followed by the same lowercase letter in the columns and uppercase letter in the rows do not differ statistically from each other at the $5 \%$ probability level according to the Tukey test. F1: coefficient of variation $=15.2 \%$ / least significant difference for column $=1.3$ / least significant difference for row $=1.2$. F2: coefficient of variation $=15.4 \%$ / least significant difference for column $=1.5 /$ least significant difference for row $=1.3$. 
Table 6. Average values of linear retraction (\%) as a function of temperature and maturation time up to.

\begin{tabular}{|c|c|c|c|c|}
\hline \multirow{2}{*}{ Formulations } & \multirow{2}{*}{ Maturation time(week) } & \multicolumn{3}{|c|}{ Firing Temperature (oC) } \\
\hline & & 1200 & 1300 & 1400 \\
\hline \multirow{4}{*}{$\mathrm{F} 1$} & $1^{\text {st }}$ & $9.5 \mathrm{aC}$ & $13.5 \mathrm{aB}$ & $14.9 \mathrm{abA}$ \\
\hline & $2^{\text {nd }}$ & $8.2 \mathrm{bC}$ & $13.3 \mathrm{abB}$ & $15.2 \mathrm{abA}$ \\
\hline & $3^{\text {rd }}$ & $9.4 \mathrm{abC}$ & $13.5 \mathrm{aB}$ & $15.5 \mathrm{aA}$ \\
\hline & $4^{\text {th }}$ & $9.3 \mathrm{abC}$ & $12.9 \mathrm{bB}$ & $14.8 \mathrm{bA}$ \\
\hline \multirow{4}{*}{$\mathrm{F} 2$} & $1^{\mathrm{st}}$ & $9.1 \mathrm{aC}$ & $12.2 \mathrm{aB}$ & $14.2 \mathrm{aA}$ \\
\hline & $2^{\text {nd }}$ & $8.8 \mathrm{aC}$ & $11.1 \mathrm{bB}$ & $13.4 \mathrm{bA}$ \\
\hline & $3^{\text {rd }}$ & $8.8 \mathrm{aC}$ & $10.6 \mathrm{bB}$ & $13.8 \mathrm{abA}$ \\
\hline & $4^{\text {th }}$ & $8.0 \mathrm{bC}$ & $10.7 \mathrm{bB}$ & $13.6 \mathrm{abA}$ \\
\hline
\end{tabular}

Note: The averages followed by the same lowercase letter in the columns and uppercase letter in the rows do not differ statistically from each other at the $5 \%$ probability level according to the Tukey test. F1: coefficient of variation $=3.7 \%$ / least significant difference for column $=0.5$ / least significant difference for row $=0.5$. F2: coefficient of variation $=5.4 \%$ / least significant difference for column $=0.7$ / least significant difference for row $=0.6$.

Table 7. Mean values of flexural strength $(\mathrm{MPa})$ as a function of temperature and maturation time up to.

\begin{tabular}{lcccc}
\hline \multirow{2}{*}{ Formulations } & $\begin{array}{c}\text { Maturation } \\
\text { time(week) }\end{array}$ & \multicolumn{3}{c}{ Firing Temperature $\left({ }^{\circ} \mathbf{C}\right)$} \\
\cline { 2 - 4 } & $1^{\text {st }}$ & $24.1 \mathrm{aC}$ & $\mathbf{1 3 0 0}$ & $\mathbf{1 4 0 0}$ \\
$\mathrm{n}$ F1 & $2^{\text {nd }}$ & $22.5 \mathrm{aC}$ & $32.8 \mathrm{aB}$ & $40.3 \mathrm{aA}$ \\
& $3^{\text {rd }}$ & $23.1 \mathrm{aC}$ & $32.8 \mathrm{aB}$ & $43.5 \mathrm{aA}$ \\
& $4^{\text {th }}$ & $23.0 \mathrm{aC}$ & $32.5 \mathrm{aB}$ & $42.1 \mathrm{aA}$ \\
& $1^{\text {st }}$ & $25.3 \mathrm{aC}$ & $30.2 \mathrm{aB}$ & $42.8 \mathrm{aA}$ \\
$\mathrm{F} 2$ & $2^{\text {nd }}$ & $25.9 \mathrm{aC}$ & $31.4 \mathrm{aB}$ & $40.4 \mathrm{aA}$ \\
& $3^{\text {rd }}$ & $28.1 \mathrm{aC}$ & $32.8 \mathrm{aB}$ & $43.2 \mathrm{aA}$ \\
& 4 th & $28.4 \mathrm{aC}$ & $34.9 \mathrm{aB}$ & $44.2 \mathrm{aA}$ \\
\hline
\end{tabular}

Note: The averages followed by the same lowercase letter in the columns and uppercase letter in the rows do not differ statistically from each other at the $5 \%$ probability level according to the Tukey test. F1: coefficient of variation $=9.6 \%$ / least significant difference for column $=3.6 /$ least significant difference for row $=3.3$. F2: coefficient of variation $=11.4 \% /$ least significant difference for column $=$ 4.6 / least significant difference for row $=4.2$.

From the data in Table 7 for formulations F1 and F2, it can be verified that the mechanical strength did not vary significantly with the maturation time. With regard to the firing temperature, a higher mechanical resistance was observed for a temperature of $1400^{\circ} \mathrm{C}$. The maturation time probably did not have much influence due to the compositions having a low organic matter content, influenced by an increase in the degree of hydration and, consequently, greater plasticity and workability.

For the lowest firing temperature $\left(1200^{\circ} \mathrm{C}\right)$, the size of the mullite crystals likely did not favor greater interlocking of the mullite needles. When the firing temperature increases to $1400^{\circ} \mathrm{C}$, the length of the mullite crystals increases and a more organized mullite structure is generated, with more interlacing, resulting in increased mechanical characteristics ${ }^{1,12,41}$.

The flexural strength values suggest some refractory ceramic product applications, such as: refractory bricks, furnace linings, crucibles, and white ceramic products, more specifically porcelains ${ }^{27}$.

\section{Conclusions}

Through analysis of the compositions and the processing variables, it was observed that the chemical composition and the maturation time do not significantly affect the linear retraction and mechanical resistance; however, improvement in mechanical strength was observed with increased firing temperature, due to the crystalline phases (mullite and cristobalite) formed. Through morphological analyses, it can be observed that the mullite needles have a tendency to preferentially orient themselves parallel to the direction of extrusion (represented by the arrow in Figure 3 (b)) that resulted from the shear stress. Furthermore, a higher degree of interlocking of the mullite needles was obtained at a temperature of $1400^{\circ} \mathrm{C}$.

\section{Acknowledgements}

The authors would like to thank CAPES and CNPq for their financial support. Thanks also to CETENE (Strategic 
Technology Center of the Northeast) for carrying out the microstructural characterization.

\section{References}

1. Gridi-Bennadji F, Chateigner D, Di Vita G, Blanchart P. Mechanical properties of textured ceramics from muscovitekaolinite alternate layers. Journal of the European Ceramic Society. 2009;29(11):2177-2184.

2. Barnes GE. Workability of clay mixtures. Applied Clay Science. 2018;153:107-112.

3. Bell FG. Lime stabilization of clay minerals and soils. Engineering Geology. 1996;42(4):223-237.

4. Deniel S, Tessier-Doyen N, Dublanche-Tixier C, Chateigner D, Blanchart P. Processing and characterization of textured mullite ceramics from phyllosilicates. Journal of the European Ceramic Society. 2010;30(12):2427-2434.

5. Boussois K, Deniel S, Tessier-Doyen N, Chateigner D, Dublanche-Tixier C, Blanchart P. Characterization of textured ceramics containing mullite from phyllosilicates. Ceramics International. 2013;39(5):5327-5333.

6. Cartaxo JM, Bastos PM, Santana LNL, Menezes RR, Neves GA, Ferreira HC. Estudo de novas ocorrências de argilas plásticas (ball clays) do nordeste do Brasil para uso em cerâmicas refratárias. Cerâmica. 2016;62(364):338-344.

7. Figueiredo JMR, Fernandes IMM, Silva VJ, Neves GA, Ferreira HC, Santana LNL. Influência da composição e das variáveis de processamento de formulações à base de argilas - uso em materiais refratários. Cerâmica. 2018;64(369):10-19.

8. Kenfaui D, Chateigner D, Gomina M, Noudem JG. Anisotropy of the Mechanical and Thermoelectric Properties of Hot-Pressed Single-Layer and Multilayer Thick $\mathrm{Ca}_{3} \mathrm{Co}_{4} \mathrm{O}_{9}$ Ceramics. International Journal of Applied Ceramic Technology. 2011;8(1):214-226.

9. Romagnoli M, Gualtieri ML, Gualtieri AF, Šliteris R, Kažys R, Tari G. Anisotropy of green stoneware evaluated by ultrasound measurements in combination with texture analyses. Journal of the European Ceramic Society. 2013;33(13-14):2785-2792.

10. Krakowiak KJ, Lourenço PB, Ulm FJ. Multitechnique Investigation of Extruded Clay Brick Microstructure. Journal of the American Ceramic Society. 2011;94(9):3012-3022.

11. Zhang T, Blackburn S, Bridgwatert J. The orientation of binders and particles during ceramic injection moulding. Journal of the European Ceramic Society. 1997;17(1):101-108.

12. Boussois K, Tessier-Doyen N, Blanchart P. High-toughness silicate ceramic. Journal of the European Ceramic Society. 2014;34(1):119-126.

13. Silva VJ, Silva MF, Gonçalves WP, Menezes RR, Neves GA, Lira HL, et al. Porous mullite blocks with compositions containing kaolin and alumina waste. Ceramics International. 2016;42(14):15471-15478.

14. Magliano MVM, Pandolfelli VC. Mulitização em refratários utilizando diferentes fontes precursoras: revisão. Cerâmica. 2010;56(340):368-375.
15. Schneider H, Schreuer J, Hildmann B. Structure and properties of mullite - A review. Journal of the European Ceramic Society. 2008;28(2):329-344.

16. Santana LNL, Gomes J, Neves GA, Lira HL, Menezes RR, Segadães AM. Mullite formation from bentonites containing kaolinite: Effect of composition and synthesis parameters. Applied Clay Science. 2014;87:28-33.

17. De Aza AH, Turrillas X, Rodriguez MA, Duran T, Pena P. Time-resolved powder neutron diffraction study of the phase transformation sequence of kaolinite to mullite. Journal of the European Ceramic Society. 2014;34(5):1409-1421.

18. Zhou Z, Jin G, Liu H, Wu J, Mei J. Crystallization mechanism of zeolite A from coal kaolin using a two-step method. Applied Clay Science. 2014;97-98:110-114.

19. Raghdi A, Heraiz M, Sahnoune F, Saheb N. Mullite-zirconia composites prepared from halloysite reaction sintered with boehmite and zirconia. Applied Clay Science. 2017;146:70-80.

20. Van Vlack LH. Propriedades dos Materiais Cerâmicos. São Paulo: Edgard Blucher; 1973.

21. Żbik MS, Song YF, Frost RL. Kaolinite flocculation induced by smectite addition - A transmission X-ray microscopic study. Journal of Colloid and Interface Science. 2010;349(1):86-92.

22. Lecomte-Nana G, Mokrani A, Tessier-Doyen N, Boussois K, Goure-Doubi H. Texturation of model clay materials using tape casting and freezing. Ceramics International. 2013;39(8):90479053.

23. Associação Brasileira de Normas Técnicas (ABNT). NBR 6459: Solo - Determinação do limite de liquidez. Rio de Janeiro: ABNT; 2016.

24. Associação Brasileira de Normas Técnicas (ABNT). NBR 7180: Solo - Determinação do limite de plasticidade. Rio de Janeiro: ABNT; 2016.

25. Silva FAS, Azevedo CAV. Principal Components Analysis in the software Assistat-Statistical Attendance. In: 7th World Congress on Computers in Agriculture; 2009 Jun 22-24; Reno, NV, USA.

26. Mahmoudi S, Bennour A, Meguebli A, Srasra E, Zargouni F. Characterization and traditional ceramic application of clays from the Douiret region in South Tunisia. Applied Clay Science. 2016;127-128:78-87.

27. Santos PS. Ciência e Tecnologia de Argilas. Volume 1. $2^{\mathrm{a}}$ ed. São Paulo: Edgard Blücher; 1989.

28. Nzeugang Nzeukou A, Fagel N, Njoya A, Belaya Kamgang V, Eko Medjo R, Chinje Melo U. Mineralogy and physicochemical properties of alluvial clays from Sanaga valley (Center, Cameroon): Suitability for ceramic application. Applied Clay Science. 2013;83-84:238-243.

29. Caputo HP, Caputo AN. Mecânica dos Solos e Suas Aplicações - Fundamentos. Volume 1. $7^{\mathrm{a}}$ ed. Rio de Janeiro: LTC; 2015.

30. Santos PS. Ciência e Tecnologia de Argilas. Volume 2. $2^{\mathrm{a}}$ ed. São Paulo: Edgard Blücher; 1992.

31. Alves HPA, Silva JB, Campos LFA, Torres SM, Dutra RPS, Macedo DA. Preparation of mullite based ceramics from clay-kaolin waste mixtures. Ceramics International. 2016;42(16):1908619090. 
32. McConville CJ, Lee WE. Microstructural Development on Firing Ilite and Smectite Clays Compared with that in Kaolinite. Journal of the American Ceramic Society. 2005;88(8):22672276.

33. Gonçalves WP, Silva VJ, Menezes RR, Neves GA, Lira HL, Santana LNL. Microstructural, physical and mechanical behavior of pastes containing clays and alumina waste. Applied Clay Science. 2017;137(1):259-265.

34. Chen CY, Lan GS, Tuan WH. Microstructural evolution of mullite during the sintering of kaolin powder compacts. Ceramics International. 2000;26(7):715-720.

35. Li J, Lin H, Li J, Wu J. Effects of different potassium salts on the formation of mullite as the only crystal phase in kaolinite. Journal of the European Ceramic Society. 2009;29(14):29292936.

36. Aras A. The differences between alkaline- and alkaline-earthflux effects on high-temperature phase change of clay based ceramic. Applied Clay Science. 2018;164:2-12.

37. Bartonickova E, Ptacek P, Opravil T, Soukal F, Masilko J, Novotny R, et al. Mullite-based refractories fabricated by foam casting. Ceramics International. 2015;41(10 Pt B):14116-14123.

38. Lee S, Kim YJ, Moon HS. Phase Transformation Sequence from Kaolinite to Mullite Investigated by an Energy-Filtering Transmission Electron Microscope. Journal of the American Ceramic Society. 1999;82(10):2841-2848.

39. Lee WE, Souza GP, McConville CJ, Tarvornpanich T, Iqbal, Y. Mullite formation in clays and clay-derived vitreous ceramics. Journal of the European Ceramic Society. 2008;28(2):465-471.
40. Martín-Márquez J, Rincón JM, Romero M. Effect of microstructure on mechanical properties of porcelain stoneware. Journal of the European Ceramic Society. 2010;30(15):3063-3069.

41. Boussois K, Tessier-Doyen N, Blanchart P. Anisotropic kinetic of the kaolinite to mullite reaction sequence in multilayer ceramics. Journal of the European Ceramic Society. 2013;33(2):243-249.

42. Luo Y, Ma S, Zheng S, Liu C, Han D, Wang X. Mullite-based ceramic tiles produced solely from high-alumina fly ash: Preparation and sintering mechanism. Journal of Alloys and Compounds. 2018;732:828-837.

43. Piva DH, Piva RH, Venturini J, Morelli MR, Bergmann CP. Microestrutura, fases cristalinas e propriedades elétricas de porcelanas aluminosas contendo diferentes concentrações de $\mathrm{Fe} 2 \mathrm{O} 3$ sinterizadas em atmosfera redutora e oxidante. Cerâmica. 2015;61(359):374-382.

44. Chen YF, Wang MC, Hon MH. Phase transformation and growth of mullite in kaolin ceramics. Journal of the European Ceramics Society. 2004;24(8):2389-2397.

45. Bourret J, Tessier-Doyen N, Guinebretiere R, Joussein E, Smith DS. Anisotropy of thermal conductivity and elastic properties of extruded clay-based materials: Evolution with thermal treatment. Applied Clay Science. 2015;116-117:150-157.

46. Vieira CMF, Monteiro SN, Duailibi Filho J. Formulação de Massa de Revestimento Cerâmico com Argilas Plásticas de Campos dos Goytacazes (RJ) e Taguá(SP). Cerâmica Industrial. 2001;6(6):4349.

47. Santos CP, Oliveira HA, Oliveira RMPB, Macedo ZS. Caracterização de argilas calcárias utilizadas na produção de revestimentos cerâmicos no Estado de Sergipe - Brasil. Cerâmica. 2016;62(362):147-156. 